\title{
Exploring potential power of corporate social responsibility toward sustainability development: analysis of state-owned company social responsibility in Indonesia
}

\section{Dianne Frisko}

The University of Surabaya,

Faculty of Business and Economics,

Jl. Raya Kalirungkut, Surabaya 60293, Indonesia

E-mail: dianne@ubaya.ac.id

\begin{abstract}
The implementation of corporate social responsibility (CSR) in Indonesia is mostly forced to follow government rules. Government also enacted some regulations that all state-owned companies (SOCs) allocate some of their profits in CSR programs. This paper attempts to analyse the effectiveness of CSR programs run by SOCs, and to assess the contributions of those programs in addressing social and environmental issues - which have been a government agenda. The findings of this paper reveal that government have fostered SOCs to prioritise strengthening economic programs for small-medium enterprises (SMEs). In the other sites, government has minimum attention to encourage SOCs to empower potential rural areas' economic development as well as to overcome their social issues. The results of this paper are to provide information as guidance for government and SOCs to align each social mission through social responsibility programs in creating sustainable development.
\end{abstract}

Keywords: corporate social responsibility; CSR; state-owned company; SOC; sustainability development.

Reference to this paper should be made as follows: Frisko, D. (2012) 'Exploring potential power of corporate social responsibility toward sustainability development: analysis of state-owned company social responsibility in Indonesia', Int. J. Sustainable Strategic Management, Vol. 3, No. 3, pp.205-220.

Biographical notes: Dianne Frisko is a Lecturer in Accounting at the Faculty of Business and Economics - The University of Surabaya, Indonesia. Her research interests include corporate social responsibility, environmental accounting and strategic performance measures. She has joined some environmental accounting projects, and she also has published papers at international conference and in refereed journals.

This paper is a revised and expanded version of a paper entitled 'Aligning corporate social responsibility with government social mission in creating sustainability development' presented at SIBR Conference on Interdisciplinary Business and Economic Research, Bangkok, June 2011. 